\title{
Uterine Corpus Leiomyoma
}

National Cancer Institute

\section{Source}

National Cancer Institute. Uterine Corpus Leiomyoma. NCI Thesaurus. Code C3434.

A benign smooth muscle neoplasm arising from the body of the uterus. It is

characterized by the presence of spindle cells with cigar-shaped nuclei, interlacing fascicles, and a whorled pattern. 